\title{
Kontribusi Kreativitas dan Kebiasaan Belajar Terhadap Hasil Belajar Instalasi Penerangan Listrik Siswa Kelas XI
}

\author{
Eka Ratna Sari ${ }^{1 *}$, Hasan Maksum ${ }^{2}$ (iD \\ 1,2 Program Pascasarjana Fakultas Teknik, Universitas Negeri Padang, Padang, Indonesia \\ *Corresponding author: ratnasari4eka@gmail.com
}

\begin{abstract}
Abstrak
Masalah penelitian ini yakni pada masa pandemi Covid-19 menyebabkan pembelajaran tatap muka digantikan dengan pembelajaran daring. Siswa dan guru belum terbiasa belajar daring dengan berbagai aplikasi E-Learning sehingga berdampak pada hasil belajar. Untuk dapat mencapai hasil belajar yang baik siswa dituntut untuk memiliki kreativitas dan kebiasaan belajar yang baik. Untuk itu penelitian ini bertujuan untuk melihat seberapa besar hubungan kreativitas terhadap hasil belajar IPL, hubungan kebiasaan belajar terhadap hasil belajar, hubungan kreativitas dan kebiasaan belajar terhadap hasil belajar. Penelitian ini merupakan penelitian korelasional. Subjek penelitiannya siswa kelas XI TITL yang mengikuti pembelajaran mata pelajaran Instalasi Penerangan Listrik. Data penelitian diperoleh dengan menggunakan angket untuk melihat kreativitas dan kebiasaan belajar serta nilai rapor tengah semester untuk melihat hasil belajar IPL. Hasil penelitian adalah terdapat hubungan positif dan signifikan antara kreativitas dengan hasil belajar IPL dengan nilai $r$ hitung 0,458 dengan kategori korelasi sedang dan berkontribusi sebesar 20,97\%. Terdapat hubungan yang positif dan signifikan antara kebiasaan belajar dengan hasil belajar IPL dengan nilai $r_{h i t u n g}$ 0,648 dengan kategori korelasi kuat dan berkontribusi sebesar 41,99\%. Terdapat hubungan yang positif dan signifikan antara kreativitas dan kebiasaan belajar terhadap hasil belajar IPL dengan $\mathrm{r}_{\text {hitung }}$ 0,662 dengan kategori korelasi kuat dan berkontribusi sebesar 43,9\%. Dapat disimpulkan terdapat hubungan kreativitas terhadap hasil belajar IPL, terdapat hubungan kebiasaan belajar terhadap hasil belajar, dan terdapat hubungan kreativitas dan kebiasaan belajar terhadap hasil belajar.
\end{abstract}

Kata kunci: Kreativitas, Kebiasaan Belajar, Hasil Belajar

\section{Abstract}

The problem with this research is that during the Covid-19 pandemic, face-to-face learning was replaced by online learning. Students and teachers are not used to learning online with various E-Learning applications so that it has an impact on learning outcomes. To be able to achieve good learning outcomes, students are required to have creativity and good study habits. For this reason, this study aims to see how big the relationship between creativity and IPL learning outcomes, the relationship between study habits and learning outcomes, the relationship between creativity and study habits and learning outcomes. This research is a correlational study. The research subjects were students of class XI TITL who took lessons in Electrical Lighting Installation subjects. The research data was obtained by using a questionnaire to see creativity and study habits as well as mid-semester report cards to see IPL learning outcomes. The result of the research is that there is a positive and significant relationship between creativity and IPL learning outcomes with an $r$ value of 0.458 with a moderate correlation category and a contribution of $20.97 \%$. There is a positive and significant relationship between study habits and IPL learning outcomes with an rcount of 0.648 with a strong correlation category and a contribution of 41.99\%. There is a positive and significant relationship between creativity and study habits on IPL learning outcomes with rcount 0.662 with a strong correlation category and a contribution of $43.9 \%$. It can be concluded that there is a relationship between creativity and IPL learning outcomes, there is a relationship between study habits and learning outcomes, and there is a relationship between creativity and study habits on learning outcomes.

Keywords: Creativity, Study Habits, Learning Outcomes

$\begin{array}{ll}\text { History: } & \\ \text { Received } & : \text { 4 Januari } 2021 \\ \text { Revised } & : \text { 21 Januari } 2021 \\ \text { Accepted } & : \text { 20 Maret } 2021 \\ \text { Published } & : 25 \text { Maret } 2021\end{array}$

Publisher: Undiksha Press

Licensed: This work is licensed under

a Creative Commons Attribution 4.0 License

Accepted : 20 Maret 2021 


\section{Pendahuluan}

Pandemi Covid-19 menyebabkan berbagai dampak pada dunia pendidikan (Mastura dan Rustan Santaria, 2020; Siahaan, 2020). Pemerintah mengeluarkan kebijakan dengan menerapkan pembelajaran jarak jauh pada semua jenjang pendidikan. Pendidikan dapat tetap berlangsung selama pandemi Covid-19 melalui pembelajaran jarak jauh (Purwanto, 2020; Syah, 2020). Sekolah Menengah Kejuruan (SMK) merupakan salah satu lembaga pendidikan kejuruan yang memiliki tugas untuk mempersiapkan tenaga kerja tingkat menengah yang beriman, produktif, kreatif, inovatif, berkarakter dan mampu bersaing sesuai dengan bidangnya masing-masing (Mukhlason et al., 2020). Pada Sekolah Menengah Kejuruan (SMK) terdapat mata pelajaran Instansi Penerangan Listrik (IPL). Instalasi Penerangan Listrik (IPL) merupakan salah satu mata pelajaran yang merujuk kepada kurikulum 2013. Secara garis besar tujuan mata pelajaran adalah agar siswa mampu merancang dan memasang instalasi penerangan pada bangunan sederhana hingga industri kecil serta jalan umum. Mata pelajaran IPL sebagai usaha peningkatan mutu lulusan dapat dilakukan dengan meningkatkan disiplin belajar, menerapkan metode pembelajaran yang tepat, meningkatkan kompetensi guru, melengkapi sarana dan prasarana penunjang proses belajar mengajar, serta melakukan dan mengembangkan penelitian-penelitian yang dapat meningkatan mutu pendidikan di sekolah tersebut. Mutu pendidikan di suatu sekolah dapat dilihat dari hasil belajar siswanya. Semakin baik hasil belajar siswanya, maka semakin baik pula mutu pendidikan sekolah tersebut

Kenyataannya perubahan sistem pembelajaran tatap muka menjadi pembelajaran jarak jauh tentunya sangat berpengaruh terhadap hasil belajar yang diperoleh siswa (Maria Kristina Ota, Ana Maria Gadi Djou, 2021). Pada masa pandemi ini, guru dituntut menggunakan teknologi agar tujuan pembelajaran dapat tercapai (Robandi \& Mudjiran, 2020). Selain itu, guru dituntut lebih kreatif dalam pemilihan metode pembelajaran, metode penyampaian materi, pemilihan media pembelajaran yang tepat sesuai dengan karakteristik siswa (Utomo et al., 2021). Kurangnya pemahaman dan kesadaran orang tua mengenai sistem Belajar dari Rumah (BDR), sehingga menganggap bahwa anak tidak belajar/tidak sekolah karena berada di rumah. Berdasarkan hasil wawancara dengan guru mata pelajaran instalasi Penerangan Listrik yang dilakukan pada tanggal 05 September 2020, diperoleh informasi bahwa masih banyak siswa yang harus mengikuti remedial untuk dinyatakan tuntas dalam mata pelajaran ini. Dari data hasil belajar siswa terlihat bahwa kurang dari $60 \%$ siswa yang belum dinyatakan tuntas atau memperoleh nilai dibawah Skor Ketuntasan Minimal (SKM) pada saat dilakukan penilaian mata pelajaran IPL yang merupakan kelompok muatan peminatan kejuruan (C3) ini batas SKM nya adalah 65.

Beberapa faktor yang mempengaruhi hasil belajar siswa, baik faktor internal maupun eksternal. Salah satu faktor yang dapat mempengaruhi hasil belajar siswa adalah kreativitas. kreativitas merupakan sumber daya atau kemampuan individu untuk berkreasi (Ismayani, 2013). Siswa akan memiliki kepercayaan diri yang tinggi, pantang menyerah, imajinatif, lebih tertarik pada konsep dari pada hal-hal kecil, mampu menganalisa masalah dengan baik serta dapat mengungkapkan alternatif-alternatif pemecahan dari masalah jika siswa memiliki kreativitas (Nita, 2019). Proses pembelajaran di sekolah cenderung mengembangkan aspek kognitif sedangkan aspek kreativitas terabaikan. Dengan kata lain, konsep berfikir yang dikembangkan merupakan konsep berpikir konvergen, sehingga menghambat perkembangan kreativitas siswa. Oleh karena itu, kreativitas sangat diperlukan dalam pendidikan. Adanya kreativitas akan muncul ide-ide baru sebagai cara menghadapi berbagai kendala (Nurfitriyani, 2015). Selain kreativitas, kebiasaan belajar siswa juga mempengaruhi hasil belajarnya. keberhasilan belajar siswa dikarenakan adanya kebiasaan belajar baik (Rosyida et al., 2016). Kebiasaan belajar baik membuat siswa memperoleh prestasi belajar tinggi 
(Kuswariningsih, 2016). Kebiasaan belajar baik akan mampu menciptakan suasana belajar yang benar-benar mendukung untuk belajar. Pembelajaran memerlukan pembagian waktu, dengan adanya jadwal belajar siswa mampu membagi waktu belajarnya. Kebiasaan belajar akan mempengaruhi belajar itu sendiri, yang bertujuan untuk mendapatkan pengetahuan, sikap, kecakapan dan keterampilan, diantaranya, pembuatan jadwal dan pelaksanaannya, membaca dan membuat catatan, mengulangi bahan pelajaran, konsentrasi dan mengerjakan tugas. Di dalam proses belajar, pembiasaan menyebabkan muncul suatu pola tingkah laku baru yang relatif menetap dan otomatis.

Berdasarkan uraian di atas, faktor yang diduga paling berpengaruh dan menyebabkan rendahnya hasil belajar adalah kurangnya kreativitas siswa dan kebiasaan belajar siswa. Hal ini sejalan dengan penelitian terdahulu yang menyatakan makin tinggi kreativitas makin tinggi pula kemampuan memecahkan masalah dalam pelajaran (Sambada, 2012). Kebiasaan belajar secara signifikan berpengaruh terhadap hasil belajar siswa (Rosyida et al., 2016). Terdapat pengaruh kreativitas mahasiswa terhadap hasil belajar kalkulus (Nurfitriyani, 2015). Konsep diri dan kebiasaan belajar berpengaruh terhadap hasil belajar matematika siswa kelas VIII SMP Negeri 6 Bontomatene Kepulauan Selayar (Magfirah et al., 2015). Terdapat pengaruh yang signifikan antara kebiasaan belajar siswa terhadap hasil belajar pada mata pelajaran ekonomi siswa SMA Pembangunan Laboratorium UNP (Hendra Anggryawan, 2018). Berdasarkan uraian yang telah dipaparkan di atas, hasil belajar Instalasi Penerangan Listrik dipengaruhi dengan kreativitas dan kebiasaan belajar siswa merupakan masalah yang perlu untuk diteliti. Oleh karena itu, tujuan penelitian ini menganalisis hubungan yang positif dan signifikan antara kreativitas dan kebiasaan belajar dengan hasil belajar Instalasi Penerangan Listrik Kelas XI. Hasil penelitian ini diharapkan mampu memberi konstribusi yang signifikan dalam upaya pengoptimalan pembelajaran Instalasi Penerangan Listrik SMK Negeri 1 Tilatang Kamang.

\section{Metode}

Penelitian ini merupakan penelitian deskriptif yang bersifat korelasional, penelitian ini bertujuan untuk mengetahui bagaimana kreativitas siswa dan kebiasaan belajarsiswa serta hubungan antara kreativitas dan kebiasaan belajar terhadap hasil belajar siswa, serta menyelidiki berapa besar sumbangan kreativitas dan kebiasaan belajar terhadap hasil belajar siswa. Penelitian korelasional dirancang untuk memperoleh informasi tentang status gejala pada saat penelitian. Menurut Sugiyono (2015: 38) variabel penelitian pada dasarnya merupakan segala sesuatu yang berbentuk apa saja yang ditetapkan oleh peneliti untuk dipelajari sehingga nantinya diperoleh informasi tentang hal tersebut, dan kemudian ditarik kesimpulannya. Penelitian ini dilakukan dengan mengklasifikasi variabel penelitian kedalam dua kelompok yaitu variabel bebas dan variabel terikat. Variabel bebas pada penelitian ini adalah kreativitas $\left(\mathrm{X}_{1}\right)$ dankebiasaan belajar $\left(\mathrm{X}_{2}\right)$. Sedangkan variabel terikatnya adalah hasil belajar (Y).

Penelitian ini dilakukan pada semester Juli - Desember 2020 kepada siswa SMKN 1 Tilatang Kamang kelas XI Kompetensi Keahlian Teknik Instalasi Tenaga Listrik di SMKN 1 Tilatang Kamang yang terdaftar pada semester Juli - Desember 2020. Populasi dalam penelitian ini adalah seluruh siswa SMKN 1 Tilatang Kamang kelas XI Kompetensi Keahlian Teknik Instalasi Tenaga Listrik Tahun Pembelajaran 2020/2021 yang telah duduk di semester III dengan jumlah 45 orang. Pengambilan sampel dalam suatu penelitian perlu diperhatikan agar sampel tersebut hendaknya mewakili semua populasi. Dalam penelitian ini semua populasi dijadikan sampel karena populasi terbatas. Hal ini sesuai dengan pendapat Suharsimi Arikunto (2006:134) yang menyatakan bahwa "jika penelitian mempunyai 100 atau lebih subjek dalam populasi, ini sebaiknya diambil $25-30 \%$ dari populasi tersebut, tapi 
bila anggota tersebut kurang dari 100, maka semua populasi dijadikan sampel”. Jadi seluruh siswa yang masuk dalam populasi tersebut dijadikan sampel dalam penelitian ini.

Agar tidak terjadi salah penafsiran yang berbeda tentang variabel dalampenelitian ini, maka perlu diberikan definisi operasional sebagai berikut: 1) Hasil Belajar IPL (Y), Hasil belajar merupakan tolak ukur yang dapat digunakan untuk menentukan keberhasilan siswa dalam menguasai materi pelajaran. Sedangkan hasil belajar IPL merupakan tolak ukur yang digunakan untuk menentukan keberhasilan siswa dalam menguasai materi pelajaran IPL. Dalam penelitian ini hasil belajar IPL yang diambil adalah nilai rapor MID Semester siswa pada mata pelajaran IPL pada program keahlian Teknik Instalasi Tenaga Listrik; 2) Kreativitas $\left(\mathrm{X}_{1}\right)$. Dalam penelitian ini, kreativitas siswa dilihat dari indikator terbuka terhadap pengalaman baru, rasa ingin tahu yang besar, menyukai tugas berat dan sulit, percaya pada diri sendiri, dan berfikir fleksibel; 3) Kebiasaan Belajar $\left(\mathrm{X}_{2}\right)$, Dalam penelitian ini, kebiasaan belajar siswa dilihat dari indikator kehadiran siswa, keaktifan dalam kelas belajar, melakukan persiapan belajar dan kesulitan belajar.

Instrumen yang digunakan dalam penelitian ini adalah angket. Menurut Sugiyono (2018: 120) mengenai penyusunan instrumen penelitian, titik tolaknya adalah variable penelitian yang ditetapkan untuk diteliti, dimana prosesnya yakni dengan memberikan definisi operasional pada variable, menentukan indikator yang akan diukur, menjabarkan indikator menjadi butir pernyataan atau pertanyaan. Berdasarkan sifatnya, data yang diambil dalam penelitian ini adalah data kuantitatif yang bersifat angka. Berdasarkan sumbernya, data yang diperoleh yaitu: 1) Data Primer adalah data yang diperoleh langsung dari responden dengan membagikan angket kepada siswa kelas XI Kompetensi Keahlian Teknik Instalasi Tenaga Listrik SMKN 1 Tilatang Kamang yang telah dipilih menjadi sampel penelitian; 2) Data Sekunder adalah data yang telah lebih dulu dikumpulkan atau dilaporkan oleh orang atau instansi di luar peneliti sendiri, seperti data jumlah siswa kelas XI Kompetensi Keahlian Teknik Instalasi Tenaga Listrik SMKN 1 Tilatang Kamang.

Teknis analisis data menggunakan analisis data kuantitatif dengan menggunakan metoda statistik korelasi dan regresi yang digunakan untuk menguji hipotesis-hipotesis penelitian. Berdasarkan hal tersebut, pengujian yang dilakukan adalah uji normalitas, uji linearitas, dan uji independensi antar variabel bebas menggunakan teknik korelasi dan regresi sederhana atau dengan uji signifikan. Kriteria dari pengujian ini adalah jika $t$ hitung $>t$ tabel pada taraf kesalahan 5\%, maka Ho ditolak dan artinya signifikan. Sebaliknya, jika $\mathrm{t}$ hitung $<\mathrm{t}$ tabel pada taraf kesalahan 5\%, maka Ho diterima dan artinya tidak signifikan. Pengujian hipotesis dilakukan dengan tahap sebagai berikut: a) Hipotesis pertama dan kedua diuji dengan menggunakan teknik korelasi dan regresi sederhana, dengan tujuan untuk melihat hubungan dan bentuk linieritas antara masing-masing variabel bebas $\left(\mathrm{X}_{1}\right)$ dan $\left(\mathrm{X}_{2}\right)$ dengan variabel terikat (Y), b) Hipotesis ketiga diuji dengan menggunakan teknik korelasi dan regresi ganda, dengan tujuan untuk melihat hubungan dan bentuk garis regresi antara variabel bebas secara bersama-sama $\left(\mathrm{X}_{1.2}\right)$ dengan variabel terikat $(\mathrm{Y})$.

\section{Hasil dan Pembahasan \\ Hasil}

Data penelitian ini meliputi tiga variabel yaitu variable kreativitas $\left(\mathrm{X}_{1}\right)$, kebiasaan belajar $\left(\mathrm{X}_{2}\right)$, dan hasil belajar IPL (Y). Dari hasil penelitian yang telah dilakukan terhadap data yang ada, seluruh data yang masuk memenuhi syarat untuk diolah dan dianalisis. Berikut ini ditampilkan perhitungan statistik dasar ketiga data tersebut yang disajikan dalam Tabel 1. 
Tabel 1. Perhitungan Statistik Dasar Variabel $\mathrm{X}_{1}, \mathrm{X}_{2}$, dan $\mathrm{Y}$

\begin{tabular}{|c|c|c|c|}
\hline & Kreativitas & Kebiasaan Belajar & Hasil Belajar IPL \\
\hline \multirow{3}{*}{$\begin{array}{c}\text { Valid } \\
\text { Missing }\end{array}$} & 45 & 45 & 45 \\
\hline & 0 & 0 & 0 \\
\hline & 60.64 & 94.07 & 68.11 \\
\hline Std. Error of Mean & 1.461 & 2.044 & 1.608 \\
\hline Median & 60.00 & 94.00 & 69.00 \\
\hline Mode & 60 & 84 & 52 \\
\hline Std. Deviation & 9.803 & 13.714 & 10.786 \\
\hline Variance & 96.098 & 188.064 & 116.328 \\
\hline Range & 38 & 57 & 38 \\
\hline Minimum & 42 & 63 & 52 \\
\hline Maximum & 80 & 120 & 90 \\
\hline Sum & 2729 & 4233 & 3065 \\
\hline
\end{tabular}

\section{Variabel Kreativitas}

Data variabel kreativitas dikumpulkan melalui penyebaran angket yang terdiri dari 23 butir pernyataan yang telah diuji validitas dan realibitasnya.Selanjutnya angket diberikan kepada 45 orang responden untuk diisi secara online. Berdasarkan tabel perhitungan statistik kreativitas, dapat diketahui bahwa: $\mathrm{N}$ adalah jumlah data, dalam hal ini jumlah data yang valid ada 45 buah dan tidak ada yang hilang (missing).Mean adalah rata-rata, mean dari skor kreativitas adalah 60,64. Median adalah titik tengah, semua data diurutkan dan dibagi dua sama besar. Nilai median dari skor kreativitas adalah 60,00. Standar deviasi, yaitu ukuran penyebaran data dari rata-ratanya. Nilai standar deviasi dari skor kreativitas adalah 9,803. Minimum merupakan nilai terendah, dari skor kreativitas nilai minimum adalah 42 . Maximum adalah nilai tertinggi, dari skor kreativitas nilai maximum adalah 80. Gambaran distribusi skor kreativitas dapat dilihat pada Tabel 2 dan histogram pada Gambar 1.

Tabel 2. Distribusi Skor Variabel Kreativitas $\left(X_{1}\right)$

\begin{tabular}{lccccc}
\hline Kelas Interval & $\begin{array}{c}\text { Titik Tengah Kelas } \\
\text { Interval }\end{array}$ & Fo & \% fo & Fk & \% fk \\
\hline $42-47$ & 44,5 & 3 & 6,67 & 3 & 6,67 \\
$48-53$ & 50,5 & 8 & 17,78 & 11 & 24,45 \\
$54-60$ & 57,0 & 16 & 35,56 & 27 & 60,01 \\
$61-67$ & 64,0 & 5 & 11,11 & 32 & 71,12 \\
$68-74$ & 71,0 & 7 & 15,56 & 39 & 86,68 \\
$75-80$ & 77,5 & 6 & 13,33 & 45 & 100 \\
\hline \multicolumn{1}{c}{ Total } & & $\mathbf{4 5}$ & $\mathbf{1 0 0}$ & & \\
\hline
\end{tabular}

Gambar 1 menunjukkan bahwa frekuensi terbanyak skor kreativitas adalah antara 5460 yaitu sebanyak 16 orang atau sebesar 35,56\%. Sedangkan frekuensi terendah skor kreativitas adalah antara $42-47$ yaitu sebanyak 3 orang atau 6,67\%. Berdasarkan hasil perhitungan tingkat pencapaian responden pada variabel kreativitas dan pengklasifikasian kategori tingkat pencapaian, dapat diketahui rata-rata tingkat pencapaian skor kreativitas adalah sebesar $65,91 \%$ dan masuk kedalam kategori cukup. 


\section{Variabel Kebiasaan Belajar}

Data variabel kebiasaan belajar dikumpulkan melalui penyebaran angket yang terdiri dari 37 butir pernyataan yang telah diuji validitas dan realibitasnya.Selanjutnya angket diberikan kepada 45 orang responden untuk diisi. Berdasarkan Tabel perhitungan statistik kebiasaan belajar, dapat diketahui bahwa: $\mathrm{N}$ adalah jumlah data, dalam hal ini jumlah data yang valid ada 41 buah dan tidak ada yang hilang (missing). Mean adalah rata-rata, mean dari skor kebiasaan belajar adalah 94,07. Median adalah titik tengah, semua data diurutkan dan dibagi dua sama besar. Nilai median dari skor kebiasaan belajar adalah 94,00. Standar deviasi, yaitu ukuran penyebarandata dari rata-ratanya. Nilai standar deviasi dari skor kebiasaan belajar adalah 13,714. Minimum merupakan nilai terendah, dari skor kebiasaan belajar nilai minimumnya adalah 63. Maximum adalah nilai tertinggi, dari skor kebiasaan belajar nilai maximumnya adalah 120. Gambaran distribusi skor kebiasaan belajar dapat dilihat pada Tabel 3 dan histogram pada Gambar 2 berikut.

Tabel 3. Distribusi Skor Variabel Kebiasaan Belajar $\left(\mathrm{X}_{2}\right)$

\begin{tabular}{lccccc}
\hline $\begin{array}{c}\text { Kelas } \\
\text { Interval }\end{array}$ & Titik Tengah Kelas Interval & Fo & \% fo & Fk & \% fk \\
\hline $63-71$ & 67,0 & 2 & 4,44 & 2 & 4,44 \\
$72-81$ & 76,5 & 5 & 11,11 & 7 & 15,55 \\
$82-91$ & 86,5 & 12 & 26,67 & 19 & 42,22 \\
$92-101$ & 96,5 & 14 & 31,11 & 33 & 73,33 \\
$102-111$ & 106,5 & 7 & 15,56 & 40 & 88,89 \\
$112-120$ & 116,0 & 5 & 11,11 & 45 & 100,00 \\
\hline \multicolumn{1}{c}{ Total } & $\mathbf{4 5}$ & $\mathbf{1 0 0}$ & & \\
\hline
\end{tabular}

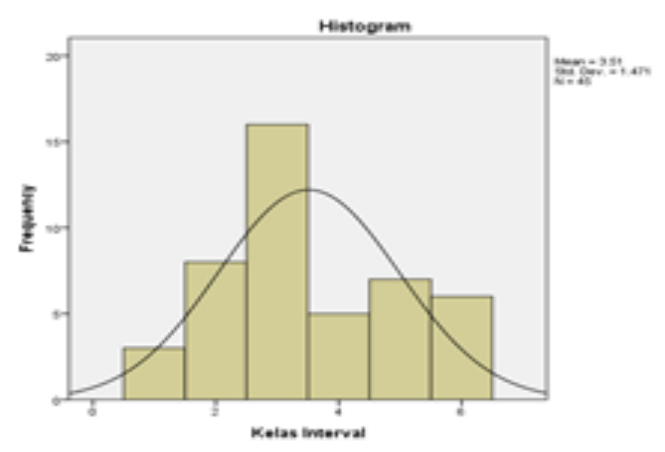

Gambar 1. Histogram Skor Kelas Interval Variabel Kreativitas $\left(\mathrm{X}_{1}\right)$

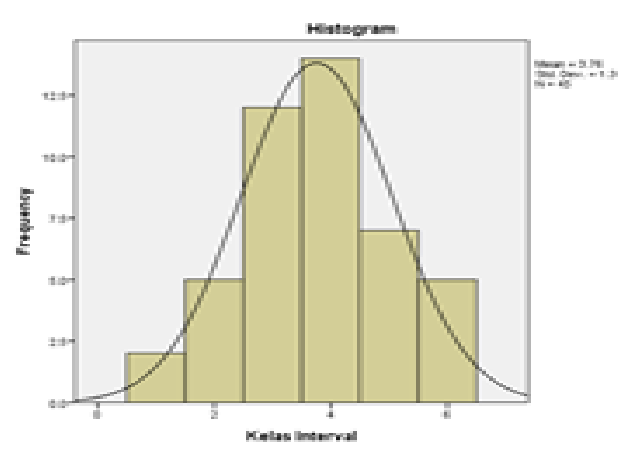

Gambar 2. Histogram Skor Kelas Interval Variabel Kebiasaan Belajar $\left(\mathrm{X}_{2}\right)$

Gambar 2 tersebut menunjukkan bahwa frekuensi terbanyak skor kebiasaan belajar adalah antara 92 - 101 yaitu sebanyak 14 orang atau 31,11\%. Sedangkan frekuensi terendah skor kebiasaan belajar adalah antara 63 - 71 yaitu sebanyak 2 orang atau 4,44\%. Berdasarkan hasil perhitungan tingkat pencapaian responden pada variabel kebiasaan belajar dan pengklasifikasian kategori tingkat pencapaian, dapat diketahui rata-rata tingkat pencapaian skor kebiasaan belajar adalah sebesar 63,56\% dan masuk kedalam kategori cukup.

\section{Variabel Hasil Belajar IPL}

Data variabel hasil belajar IPL siswa diperoleh dari arsip nilai rapor MID semester ganjil kelas XI TITL 1 dan XI TITL 2 SMKN 1 Tilatang Kamang TP. 2020-2021. Data yang 
diambil adalah 45 responden sebagai sampel penelitian. Berdasarkan tabel perhitungan statistik hasil belajar IPL, dapat diketahui bahwa: $\mathrm{N}$ adalah jumlah data, dalam hal ini jumlah data yang valid ada 45 buah dan tidak ada yang hilang (missing). Mean dari skor hasil belajar IPL adalah 68,11. Median adalah titik tengah, semua data diurutkan dan dibagi dua sama besar. Nilai median dari skor hasil belajar produktif adalah 69,00. Standar deviasi, yaitu ukuran penyebaran data dari rata-ratanya. Nilai standar deviasi dari skor hasil belajar IPL adalah 10,786. Minimum merupakan nilai terendah.Nilai hasil belajar IPL minimum adalah 52. Maximum adalah nilai tertinggi. Nilai hasil belajar IPL maximum adalah 90. Gambaran distribusi skor hasil belajar IPL dapat dilihat pada Tabel 4 dan histogram pada Gambar 3.

Tabel 4. Distribusi Frekuensi Skor Variabel Hasil Belajar IPL (Y)

\begin{tabular}{lccccc}
\hline Kelas Interval & Titik Tengah Kelas Interval & Fo & \% fo & Fk & \% fk \\
\hline $52-57$ & 54,5 & 9 & 20,00 & 9 & 20 \\
$58-63$ & 60,5 & 7 & 15,56 & 16 & 35,56 \\
$64-70$ & 67,0 & 10 & 22,22 & 26 & 57,78 \\
$71-77$ & 74,0 & 9 & 20,00 & 35 & 77,78 \\
$78-84$ & 81,0 & 8 & 17,78 & 43 & 95,56 \\
$85-90$ & 87,5 & 2 & 4,44 & 45 & 100 \\
\hline \multicolumn{1}{c}{ Total } & & $\mathbf{4 5}$ & $\mathbf{1 0 0}$ & & \\
\hline
\end{tabular}

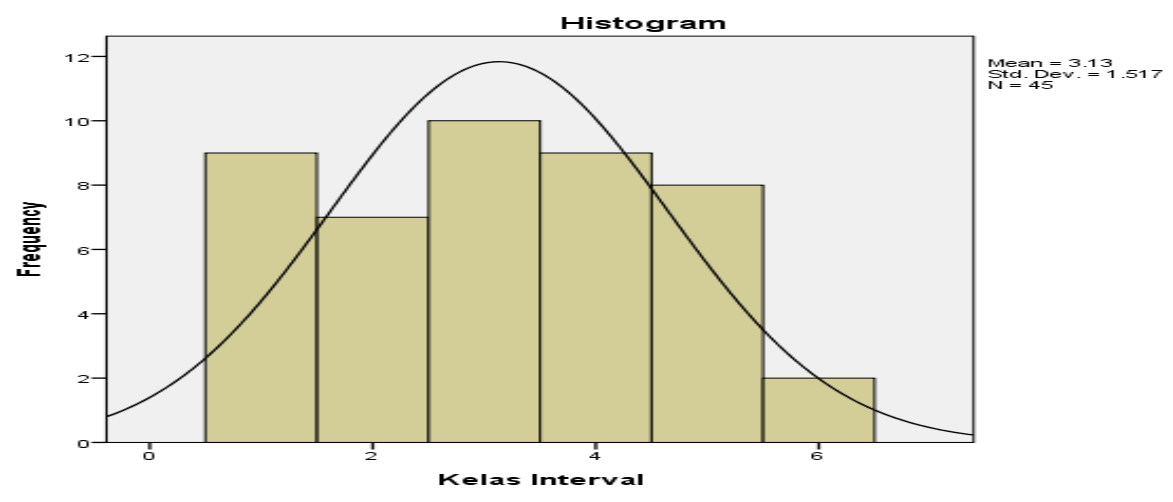

Gambar 3. Histogram Skor Kelas Insterval Variabel Hasil Belajar IPL (Y)

Gambar 3 tersebut menunjukkan bahwa frekuensi terbanyak skor Hasil Belajar IPL adalah antara 64 - 70 yaitu sebanyak 10 orang atau 22,22\%. Sedangkan frekuensi terendah skor Hasil Belajar IPL adalah antara 85 - 90 yaitu sebanyak 2 orang atau 4,44\%. Berdasarkan hasil perhitungan tingkat pencapaian responden pada variabel hasil belajar IPL dan pengklasifikasian kategori tingkat pencapaian, dapat diketahui rata-rata tingkat pencapaian skor hasil belajar IPL adalah sebesar 68,11 \% dan masuk kedalam kategori baik. Berdasarkan hasil analisis dan pengujian hipotesis menunjukkan bahwa semua hipotesis yang diajukan dapat diterima kebenarannya secara empiris. Dengan demikian diyakini bahwa variabel bebas kreativitas dan kebiasaan belajar baik secara sendiri-sendiri maupun secara bersama mempunyai hubungan cukup kuat terhadap variabel terikat hasil belajar IPL siswa. Hal ini sejalan dengan teori-teori yang mendasari pernyataan tersebut serta didukung oleh data responden secara empiris di lapangan melalui penelitian ini. Berdasarkan hasil analisis temuan dari hasil penelitian adalah menerima pernyataan $\mathrm{H}_{1}$. Dengan demikian pernyataan Hipotesis pertama "Terdapat hubungan antara kreativitas dengan hasil belajar IPL siswa kelas XI Kompetensi Keahlian Teknik Instalasi Tenaga Listrik SMKN 1 Tilatang Kamang" dapat diterima karena nilai signifikan $<0,05$, sedangkan koefisien korelasi sebesar 0,458 yang 
hubungannya dapat dinyatakan sedang dan kreatifitas berkontribusi sebesar 20,97\% terhadap hasil belajar IPL.

Temuan dari hasil penelitian adalah menerima pernyataan $\mathrm{H}_{1}$. Dengan demikian pernyataan Hipotesis kedua "Terdapat hubungan yang signifikan antara kebiasaan belajar dengan hasil belajar siswa kelas XI Kompetensi Keahlian Teknik Instalasi Tenaga Listrik di SMKN 1 Tilatang Kamang" dapat diterima karena nilai signifikan $<0,05$, sedangkan koefisien korelasi sebesar 0,648 dengan tingkat hubungannya kuat dan kebiasaan belajar berkontribusi sebesar 41,99\% terhadap hasil belajar IPL. Temuan dari hasil penelitian adalah menerima pernyataan $\mathrm{H}_{1}$. Dengan demikian pernyataan Hipotesis ketiga "Terdapat hubungan yang signifikan antara kreativitas dan kebiasaan belajar dengan hasil belajar IPL siswa kelas XI Kompetensi Keahlian Teknik Instalasi Tenaga Listrik di SMKN 1 Tilatang Kamang" dapat diterima karena nilai signifikan $<0,05$, sedangkan koefisien korelasi sebesar 0,662 yang tingkat hubungannya dapat diklasifikasikan kedalam kategori kuat, kemudian kreatifitas dan kebiasaan belajar berkontribusi sebesar 43,9\% terhadap hasil belajar IPL.

\section{Pembahasan}

Hasil pengujian hipotesis pertama, terdapat Terdapat hubungan antara kreativitas dengan hasil belajar IPL siswa kelas XI Kompetensi Keahlian Teknik Instalasi Tenaga Listrik SMKN 1 Tilatang Kamang. Hasil penelitian menunjukkan hubungan yang kuat antara variabel kreativitas dengan hasil belajar. Sehingga Ho ditolak dan Ha diterima. Hal ini menunjukkan bahwa kreativitas berhubungan dengan hasil belajar. Kreativitas yang baik merupakan cerminan kemampuan siswa untuk melahirkan sesuatu yang baru baik berupa gagasan maupun karya nyata yang relatif berbeda dengan apa yang telah ada sebelumnya. Kreativitas merupakan kemampuan memunculkan gagasan-gagasan baru dan menerapkannya dalam pemecahan suatu masalah. Kreativitas dibutuhkan dalam merancang dan merangkai sebuah rangkaian instalasi penerangan listrik, dimana siswa harus dapat menganalisa masalah yang diberikan, menghubungkan pengetahuan-pengetahuan yang dimilikinya untuk menyelesaikan masalah tersebut, membayangkannya, menuangkannya dalam bentuk rancangan dan mencari alternatif-alternatif lain jika rancangan tersebut tidak berhasil.

Kreativitas membantu siswa lebih cepat dalam memahami pelajaran, sehingga siswa dapat mengatasi kesulitan yang ditemuinya pada saat belajar. Dengan meningkatnya pemahaman siswa dalam belajar, maka secara langsung hal ini juga akan meningkatkan hasil belajar dari siswa itu sendiri. Hasil belajar setiap siswa berbeda karena kemampuan yang dimiliki juga berbeda. Sehingga, siswa yang memiliki kreativitas tinggi tentunya akan berhubungan dengan hasil belajar. Semakin tinggi kreativitas peserta didik, maka semakin besar pula peluangnya untuk mencapai tujuan dari pendidikan (Botty, 2018; Nita, 2019). Hasil belajar yang diperoleh siswa sangat berkaitan erat dengan kreativitas yang dimilikinya.

Temuan penelitian ini sejalan dengan penelitian yang dilakukan (Nita, 2019) terdapat hubungan yang signifikan antara kreativitas belajar dengan hasil belajar bahasa Indonesia kelas X SMAN 4 Payakumbuh. Artinya semakin baik kreativitas maka hasil belajar siswa juga akan menjadi lebih baik begitu sebaliknya. Temuan lain juga menyatakan terdapat hubungan positif dan signifikan antara kreativitas belajar siswa dengan hasil belajar ilmu pengetahuan alam (Septiana et al., 2018). Hasil Pengujian hipotesis kedua, temuan dari hasil penelitian menunjukkan terdapat hubungan yang signifikan antara kebiasaan belajar dengan hasil belajar siswa kelas XI Kompetensi Keahlian Teknik Instalasi Tenaga Listrik di SMKN 1 Tilatang Kamang. Kebiasaan belajar dapat dilihat dari perilaku yang dilakukan berulangulang dan menjadi karakteristik siswa dalam mengerjakan tugas-tugas belajar baik di sekolah maupun di rumah. Kebiasaan belajar juga dapat dilihat dari cara siswa menerima pelajaran, mengerjakan tugas, memahami materi pelajaran, dan waktu belajar. Seorang siswa yang 
memiliki kebiasaan belajar yang benar akan lebih mudah dalam memahami materi pelajaran serta lebih cepat dalam mengerjakan tugas yang diberikan guru (Achyanadia, 2013).

Kebiasaan belajar itu dapat diartikan sebagai cara atau teknik siswa yang sifatnya menetap saat menerima pelajaran, membaca buku, mengerjakan tugas dan mengatur waktu dalam menyelesaikan sebuah kegiatan (Djaali, 2014). Hasil belajar yang merupakan perubahan tingkah laku perserta didik dapat dipengaruhi oleh kebiasaan belajar. Kebiasaan belajar inilah yang pada akhirnya mampu memberikan perubahan-perubahan kepada siswa, misalnya pengetahuan, sikap dan keterampilannya. Dari sini dapat terlihat jelas pengaruh dari kebiasaan belajar siswa terhadap hasil belajar IPL. Temuan ini sejalan dengan penelitian yang menyatakan terdapat hubungan yang signifikan antara kebiasaan belajar dengan hasil belajar. Kebiasaan belajar siswa didominasi oleh kebiasaan belajar gerak dan verbal. Hal tersebut dikarenakan mata pelajaran sistem pengapian sebagian besar adalah mata pelajaran praktikum yang membutuhkan gerak (praktik untuk membongkar dan memasang) dan hapalan yang bagus dalam proses pembelajarannya (Ningtyas et al., 2015).

Hasil pengujian hipotesis ketiga, menunjukkan terdapat hubungan yang signifikan antara kreativitas dan kebiasaan belajar dengan hasil belajar IPL siswa kelas XI Kompetensi Keahlian Teknik Instalasi Tenaga Listrik di SMKN 1 Tilatang Kamang. Hasil belajar dapat dilihat dari kemampuan yang diperoleh siswa setelah siswa melalui atau mengikuti kegiatan belajar berupa pengalaman dan mencakup ranah kognitif, afektif dan psikomotor dan hasil belajar ini dapat digunakan sebagai penentu berhasil atau tidaknya siswa dalam suatu proses belajar. Keberhasilan siswa dalam mengikuti kegiatan pembelajaran sangat bergantung pada kreativitas dan kebiasaan belajar yang dilakukan secara berkesinambungan. Sehingga akan mempengaruhi hasil belajar siswa. Temuan penelitian ini sejalan dengan penelitian terdahulu terkait adanya hubungan yang positif dan signifikan antara kreativitas dan kebiasaan belajar, sehingga guru, wali murid dan lingkungan masyarakat harus benar-benar memperhatikan secara penuh siswa berkenaan dengan pembiasaan belajar yang baik dan peningkatan kreativitas belajar(Kuswariningsih, 2016). Sehinga temuan penelitian ini, terkait kreativitas dan kebiasaan belajar berkontribusi dalam meningkatkan hasil belajar siswa khususnya di mata pelajaran Instalasi Penerangan Listrik.

\section{Simpulan}

Berdasarkan hasil dari penelitian dan pembahasan dapat diambil simpulan: Pertama, terdapat hubungan yang positif dan signifikan antara kreativitas dengan hasil belajar IPL siswa kelas XI Kompetensi Keahlian Teknik Instalasi Tenaga Listrik SMKN 1 Tilatang Kamang. Hal ini berarti bahwa semakin tinggi kreativitas maka hasil belajar IPL siswa cenderung meningkat. Kedua, terdapat hubungan yang positif dan signifikan antara kebiasaan belajar dengan hasil belajar IPL siswa kelas XI Kompetensi Keahlian Teknik Instalasi Tenaga Listrik. Hal ini berarti bahwa semakin baik kebiasaan belajar maka hasil belajar IPL siswa cenderung meningkat. Ketiga, terdapat hubungan yang positif dan signifikan antara kreaivitas dan kebiasaan belajar dengan hasil belajar IPL siswa kelas XI Kompetensi Keahlian Teknik Instalasi Tenaga Listrik. Hal ini berarti bahwa semakin tinggi kreativitas dan semakin baik kebiasaan belajar maka hasil belajar IPL siswa cenderung meningkat. Hasil penelitian, diharapkan seluruh komponen pendidikan agar mengupayakan pengoptimalan proses pembelajaran, serta dapat mengevaluasi kegiatan pembelajaran serta dapat mengembangkan kreativitas pembelajaran dan meningkatkan kebiasaan belajar yang lebih baik. 


\section{Daftar Rujukan}

Achyanadia, S. (2013). Hubungan Kebiasaan Belajar Dan Motivasi Belajar Dengan Hasil Belajar Ipa Siswa Kelas Vii Smp Negeri 1 Ciseeng. Jurnal Teknologi Pendidikan, 2(2), 1-14. https://doi.org/10.32832/tek.pend.v2i2.447.

Botty, M. (2018). Hubungan Kreativitas Dengan Hasil Belajar Siswa Kelas V Mata Pelajaran Bahasa Indonesia Di Mi Ma'had Islamy Palembang. JIP: Jurnal Ilmiah PGMI, 4(1), 41-55. https://doi.org/10.19109/jip.v4i1.2265.

Djaali. (2014). Psikologi Pendidikan. Bumi Aksara.

Hendra Anggryawan, I. (2018). Pengaruh Fasilitas Belajar dan Motivasi Belajar Terhadap Hasil Belajar Siswa Pada Mata Pelajaran Ekonomi. Jurnal Pendidikan Ekonomi (JUPE), 2(1), 19-28. https://doi.org/10.26740/jupe.v7n3.p71-75.

Ismayani, M. R. (2013). Kreativitas dalam Pembelajaran Literasi Teks Sastra. Semantik, 2(2), 67-86.

Kuswariningsih, S. (2016). Korelasi Kebiasaan Belajar, Kreatifitas Belajar dan Prestasi Belajar IPS. Jurnal Penelitian Dan Pendidikan IPS, 10(3), 389-395. http://ejournal.unikama.ac.id/index.php/JPPI

Magfirah, I., Rahman, U., \& Sulasteri, S. (2015). Pengaruh Konsep Diri Dan Kebiasaan Belajar Terhadap Hasil Belajar Matematika Siswa Kelas VIII SMP Negeri 6 Bontomatene Kepulauan Selayar. Jurnal Matematika Dan Pembelajaran, 3(03), 103116. http://journal.uin-alauddin.ac.id/index.php/Mapan/article/view/2753.

Maria Kristina Ota, Ana Maria Gadi Djou, F. F. N. (2021). Problematika Pembelajaran Daring Siswa Kelas Vii Smpn. Jurnal Pengabdian Masyarakat, 2(1), 74-81. https://doi.org/10.37478/mahajana.v2i1.769.

Mastura dan Rustan Santaria. (2020). Dampak Pandemi Covid-19 terhadap Proses Pengajaran bagi Guru dan Siswa. Jurnal Studi Guru Dan Pembelajaran, 3(2), 289295. https://doi.org/10.30605/jsgp.3.2.2020.293.

Mukhlason, A., Winanti, T., \& Yundra, E. (2020). Analisa Indikator Smk Penyumbang Pengangguran Di Provinsi Jawa Timur. Journal of Vocational and Technical Education (JVTE), 2(2), 29-36. https://journal.unesa.ac.id/index.php/JVTE/article/view/10607.

Ningtyas, S. A., Kuswana, W. S., \& Permana, T. (2015). Hubungan Antara Kebiasaan Belajar Dengan Hasil Belajar Sistem Pengapian. Journal of Mechanical Engineering Education, 2(1), 130. https://doi.org/10.17509/jmee.v2i1.1163.

Nita, O. (2019). Hubungan Kreativitas Dengan Hasil Belajar Bahasa Indonesia. Jurnal KIBASP, 3(1), 92-103. https://doi.org/10.31539/kibasp.v3i1.903.

Nurfitriyani, M. (2015). Pengaruh Kreativitas dan Kedisiplinan Mahasiswa Terhadap Hasil Belajar Kalkulus. Formatif: Jurnal Ilmiah Pendidikan MIPA, 4(3), 219-226. https://doi.org/10.30998/formatif.v4i3.157.

Purwanto, A. (2020). Studi Eksploratif Dampak Pandemi COVID-19 Terhadap Proses Pembelajaran Online di Sekolah Dasar. Journal Education, Psycology, Councelling, 2(1). https://ummaspul.e-journal.id/Edupsycouns/article/view/397.

Robandi, D., \& Mudjiran, M. (2020). Dampak Pembelajaran Dari Masa Pandemi Covid-19 terhadap Motivasi Belajar Siswa SMP di Kota Bukittinggi. Jurnal Pendidikan Tambusai, 4(3), 3498-3502. https://doi.org/10.31004/jptam.v4i3.878.

Rosyida, F., Utaya, S., \& Budijanto, B. (2016). Pengaruh Kebiasaan Belajar dan SelfEfficacy terhadap Hasil Belajar Geografi Di SMA. Jurnal Pendidikan Geografi, 21(2), 17-28. https://doi.org/10.17977/um017v21i22016p017.

Sambada, D. (2012). Peranan Kreativitas Siswa Terhadap Kemampuan Memecahkan Masalah Fisika Dalam Pembelajaran Kontekstual. Jurnal Penelitian Fisika Dan 
Aplikasinya (JPFA), 2(2), 37. https://doi.org/10.26740/jpfa.v2n2.p37-47.

Septiana, R., Gani, R. A., \& Yuyun Elizabeth. (2018). Hubungan Kreativitas Belajar Siswa Dengan Hasil Belajar Ilmu Pengetahuan Alam. Prosiding Seminar Nasional Pendidikan, l(1), 6-10. https://journal.unpak.ac.id/index.php/proceedings/article/view/1128/972.

Siahaan, M. (2020). Dampak Pandemi Covid-19 Terhadap Dunia Pendidikan. Jurnal Kajian Ilmiah, 1(1), 73-80. https://doi.org/10.31599/jki.v1i1.265.

Syah, R. H. (2020). Dampak Covid-19 pada Pendidikan di Indonesia: Sekolah, Keterampilan, dan Proses Pembelajaran. SALAM: Jurnal Sosial Dan Budaya Syar-I, 7(5). https://doi.org/10.15408/sjsbs.v7i5.15314.

Utomo, K. D., Soegeng, A. Y., Purnamasari, I., \& Amaruddin, H. (2021). Pemecahan Masalah Kesulitan Belajar Siswa Pada Masa Pandemi Covid-19 Kelas IV SD. 9(1), $1-9$. 